\title{
Genetic evaluation of Jatropha curcas: an important oilseed for biodiesel production
}

\author{
R.G. Freitas ${ }^{1}$, R.F. Missio ${ }^{2}$, F.S. Matos $^{3}$, M.D.V. Resende $^{4}$ and L.A.S. Dias ${ }^{1}$ \\ ${ }^{1}$ Departamento de Fitotecnia, Universidade Federal de Viçosa, \\ Viçosa, MG, Brasil \\ ${ }^{2}$ Universidade Federal do Paraná, Palotina, PR, Brasil \\ ${ }^{3}$ Universidade Estadual de Goiás, Ipameri, GO, Brasil \\ ${ }^{4}$ Departamento de Ciências Florestais, Embrapa Floresta, \\ Universidade Federal de Viçosa, Viçosa, MG, Brasil \\ Corresponding author: L.A.S. Dias \\ E-mail: lasdias@ufv.br
}

Genet. Mol. Res. 10 (3): 1490-1498 (2011)

Received November 8, 2010

Accepted January 3, 2011

Published July 25, 2011

DOI 10.4238/vol10-3gmr1146

\begin{abstract}
Jatropha curcas, internationally and locally known, respectively, as physic nut and pinhão manso, is a highly promising species for biodiesel production in Brazil and other countries in the tropics. It is rustic, grows in warm regions and is easily cultivated. These characteristics and high-quality oil yields from the seeds have made this plant a priority for biodiesel programs in Brazil. Consequently, this species merits genetic investigations aimed at improving yields. Some studies have detected genetic variability in accessions in Africa and Asia. We have made the first genetic evaluation of $J$. curcas collected from Brazil. Our objective was to quantify genetic diversity and to estimate genetic parameters for growth and production traits and seed oil content. We evaluated $75 \mathrm{~J}$. curcas progenies collected from Brazil and three from Cambodia. The mean oil content in the seeds was 31\%, ranging from 16 to $45 \%$. No genetic correlation between growth traits and seed oil content was found. However, high coefficients of genetic variation were found for plant height, number of branches, height of branches,
\end{abstract}


and stem diameter. The highest individual narrow-sense heritabilities were found for leaf length (0.35) and width (0.34), stem diameter (0.24) and height of branches (0.21). We used a clustering algorithm to genetically identify the closest and most distant progenies, to assist in the development of new cultivars. Geographical diversity did not necessarily represent the genetic diversity among the accessions collected. These results are important for the continuity of breeding programs, aimed at obtaining cultivars with high grain yield and high oil content in seeds.

Key words: Oil content; Genetic diversity; Heritability; Clustering; Genetic correlation

\section{INTRODUCTION}

The worldwide demand for clean, renewable and sustainable fuels to replace or supplement fossil fuels has made biofuels a great alternative. Currently, there are different types of biofuels, especially ethanol and biodiesel. Biodiesel, in particular, can be obtained from any vegetable oil or animal fat, and its production has strong social, economic and environmental advantages. According to the Brazilian Petroleum, Gas and Biofuels Agency (ANP, http://www.anp.gov.br), Brazil's National Production and Use of Biodiesel Program (PNPB), since January 2010, produces and markets the B5, represented by the mixture of $5 \%$ biodiesel with $95 \%$ oil. Brazil is among the biggest producers and consumers of biodiesel in the world with an annual production of 1.6 billion liters and an established capacity of 3.7 billion liters in 2009. In 2008, the use of biodiesel in Brazil lessened imports by 1.1 billion liters of oil, resulting in a savings of US\$976 million of foreign exchange (ANP). The main raw materials used to produce biodiesel in Brazil are soybeans, cotton and beef fat, with a contribution of about $75.0,17.8$ and $5.1 \%$, respectively, and other fatty materials account for $2.1 \%$ of production. There is a need, therefore, to diversify the production of raw material for biodiesel through the introduction of promising species, such as Jatropha curcas L.

The genus Jatropha has 170 known species (Heller, 1996), including J. curcas L., known as physic nut, a species with high potential for biodiesel production. $J$. curcas is a fast growing euphorbia shrub, reaching 6 to $12 \mathrm{~m}$ in height, with a trunk diameter greater than $20 \mathrm{~cm}$ (Dias et al., 2007; Jongschaap et al., 2007). Adapted to infertile soils and unfavorable climate for the majority of traditional food crops, J. curcas can be considered the most promising oilseed for biodiesel production in the Southeast, Midwest and Northeast of Brazil. Among the advantages of $J$. curcas cultivation, the long production cycle stands out and may extend to 40 years, and $J$. curcas has potential productivity of $2 \mathrm{t} / \mathrm{ha}$ of oil. Being perennial, it also contributes to the conservation of the soil and reduces the cost of production, an important factor for the economic feasibility of its cultivation by smallholders. Another advantage is its high-quality oil for biodiesel in high content in its seeds ( $38 \%$ on average), and its suitability for intercropping with other crops (Dias et al., 2007).

The increased interest in J. curcas for the production of biodiesel has created a demand for the development of improved cultivars. However, caution is still needed by researchers and 
especially by producers and farmers, with respect to the success of this crop for the production of biodiesel. The breeding programs with Jatropha are rare, if compared to programs for other oil species such as soybean, cotton, peanut, sunflower, and castor.

The initial phase of a breeding program usually occurs with the set up of an adequate genbank. The success of a program also depends largely on the knowledge of the genetic variability available and of estimates of genetic parameters of the main traits. The low genetic variability detected in accessions of $J$. curcas in Africa and Asia (Basha and Sujatha, 2007; Sun et al., 2008) shows the necessity of introducing new sources of genetic variation, from Latin America in particular, to be used in breeding programs. The existence of genetic variability is important in a breeding program, because from it, one can select different genotypes to produce hybrids and similar genotypes to produce lines. Evaluations of genetic variability of $J$. curcas worldwide are scarce. Thus, this study aimed to quantify the genetic variability and to estimate genetic parameters for growth traits in J. curcas L. of Brazil. Furthermore, we evaluated the genetic correlation between the growth traits and oil content of seeds.

\section{MATERIAL AND METHODS}

\section{Plant material and assessments}

In this study, we evaluated 75 progenies of $J$. curcas collected in different regions of Brazil and three progenies from Cambodia (Table 1). The progenies test was set up in a randomized complete block design with four replications and squared plots with four plants, in the experimental field of Araponga County (lat $20^{\circ} 39^{\prime} \mathrm{S}$, long $42^{\circ} 32^{\prime} \mathrm{W}$, and alt $823 \mathrm{~m}$ asl).

\section{Table 1. Characterization of Jatropha curcas progenies studied.}

\begin{tabular}{lcll}
\hline Code of progeny & Number of progeny & State of origin & Country \\
\hline UFVJC 1 to 55 & 55 & Minas Gerais & Brazil \\
UFVJC 56 to 60 & 5 & São Paulo & Brazil \\
UFVJC 61 & 1 & Tocantins & Brazil \\
UFVJC 62 to 63 & 2 & Pernambuco & Brazil \\
UFVJC 64 & 1 & Rio Grande do Norte & Brazil \\
UFVJC 65 & 1 & Ceará & Brazil \\
UFVJC 66 & 1 & Maranhão & Brazil \\
UFVJC 67 & 1 & Pará & Brazil \\
UFVJC 68 & 1 & Rondônia & Brazil \\
UFVJC 69 & 1 & Rio Grande do Sul & Brazil \\
UFVJC 70 & 1 & Mato Grosso do Sul & Brazil \\
UFVJC 71 to 72 & 2 & Mato Grosso & Brazil \\
UFVJC 73 to 75 & 3 & \#Unknown & Cambodia \\
UFVJC 76 to 78 & 3 & \#Unknown & Brazil \\
\hline
\end{tabular}

In the eighth month after planting of the test, the following traits were evaluated: plant height $(\mathrm{PH})$, height $(\mathrm{HB})$ and number of branches (NB), crown diameter (CD), stem diameter (SD), length (LL) and width of leaves (WL), and size of the petiole (SP). PH (cm) was measured from the base to the apex of the main stem, $\mathrm{CD}(\mathrm{cm})$ was measured between both ends of the plant, HB $(\mathrm{cm})$ was measured from the base to the height of the first branch, NB 
was evaluated by counting the branches coming out from the trunk, SD (mm) was measured with a digital caliper from the stem, LL $(\mathrm{cm})$ was measured from the petiole to the tip of the leaf, WL (cm) was measured between the two ends of the leaf, and SP was measured from the insertion of the stem to the insertion of the leaf. From each progeny, the leaf selected for the evaluations was the youngest and fully expanded.

In addition to the traits described above, oil content (OIL) in seeds, the weight of 100 seeds (SW100), length (LS) and width of the seeds (WS) were also evaluated in the mother plants that gave rise to the progenies. OIL was determined by nuclear magnetic resonance (Oxford Instruments), SW100 (g) was determined by weighing a random sample of 100 seeds of each mother plant, and LS and WS were measured with a digital caliper $(\mathrm{mm})$.

\section{Statistical analysis and estimates of genetic parameters}

Descriptive statistical analysis and estimates of genetic parameters were on the basis of mixed model methodology (Bernardo, 2002; Resende, 2007). The analyses were processed using the Selegen-REML/BLUP software (Resende, 2007), considering a model for open-pollinated progenies, in a randomized complete block design, with several plants per plot. The analysis of genetic correlations between traits was performed with the SAS software (SAS Institute Inc., 1989). For this, we used additive values of each trait obtained from the analyses of mixed models. The genetic diversity among progenies was measured by the Euclidean squared distance (Resende, 2007). Software Genes (Cruz, 2006) was used for UPGMA cluster analysis and the Mantel test to test its consistency.

\section{RESULTS}

\section{Descriptive analysis}

The average OIL in the $J$. curcas $\mathrm{L}$. seeds was $31 \%$ (Table 2), with a minimum of $16 \%$ and a maximum of $45 \%$, demonstrating a wide variability for this trait. The SW100 varied from 44.6 to $86.7 \mathrm{~g}$, with a mean of $63.2 \mathrm{~g}$. Descriptive statistics for the other traits are shown in Table 2.

Table 2. Statistics of evaluated traits in progenies of Jatropha curcas.

\begin{tabular}{|c|c|c|c|c|c|c|c|c|c|c|c|c|}
\hline Parameter statistics & $\mathrm{PH}(\mathrm{cm})$ & NB & $\mathrm{HB}(\mathrm{cm})$ & $\mathrm{CD}(\mathrm{cm})$ & $\mathrm{SD}(\mathrm{mm})$ & $\mathrm{LL}(\mathrm{cm})$ & WL $(\mathrm{cm})$ & $\mathrm{SP}(\mathrm{cm})$ & OIL (\%) & SW100 (g) & $\mathrm{LS}(\mathrm{mm})$ & WS (mm) \\
\hline Average & 46.88 & 1.37 & 8.37 & 38.54 & 38.20 & 11.39 & 11.66 & 11.51 & 31.01 & 63.24 & 17.75 & 10.96 \\
\hline Standard error & 0.58 & 0.02 & 0.21 & 0.42 & 0.36 & 0.06 & 0.06 & 0.10 & 0.24 & 0.62 & 0.06 & 0.03 \\
\hline Median & 48.00 & 1.00 & 8.00 & 40.00 & 41.40 & 11.50 & 12.00 & 11.50 & 30.88 & 63.30 & 17.77 & 10.94 \\
\hline Mode & 57.00 & 1.00 & 7.00 & 42.00 & 44.00 & 12.00 & 12.00 & 12.00 & 30.38 & 50.90 & 17.52 & 11.82 \\
\hline Standard deviation & 19.40 & 0.78 & 3.42 & 12.89 & 11.91 & 1.60 & 1.63 & 2.86 & 3.67 & 8.61 & 0.91 & 0.41 \\
\hline Variance & 376.26 & 0.61 & 11.72 & 166.19 & 141.78 & 2.55 & 2.64 & 8.15 & 13.50 & 74.17 & 0.83 & 0.17 \\
\hline Minimum & 5.00 & 1.00 & 2.00 & 4.00 & 3.00 & 6.00 & 5.50 & 3.00 & 15.99 & 44.60 & 15.81 & 10.02 \\
\hline Maximum & 105.00 & 7.00 & 23.00 & 79.00 & 58.71 & 18.50 & 18.50 & 21.00 & 45.55 & 86.70 & 20.00 & 12.08 \\
\hline
\end{tabular}

$\mathrm{PH}=$ plant height $\mathrm{NB}=$ number of branches; $\mathrm{HB}=$ height of branches; $\mathrm{CD}=$ crown diameter; $\mathrm{SD}=$ stem diameter; $\mathrm{LL}=$ length of leaves; $\mathrm{WL}=$ width of leaves; $\mathrm{SP}=$ size of the petiole; $\mathrm{OIL}=$ oil content; SW100 = weight of 100 seeds; $\mathrm{LS}=$ length of the seeds; WS $=$ width of the seeds. 


\section{Estimates of genetic parameters}

Traits $\mathrm{PH}, \mathrm{HB}, \mathrm{NB}$, and $\mathrm{CD}$ showed considerable genetic variability (Table 3), especially $\mathrm{HB}(\mathrm{CVgi}=17.9 \%), \mathrm{PH}(\mathrm{CVgi}=16.3 \%)$ and $\mathrm{NB}(\mathrm{CVgi}=16.0 \%)$. Traits $\mathrm{CD}$, SP, WL, and LL showed genotypic coefficients of variation of less magnitude, 7.4, 7.7, 7.8, and $7.8 \%$, respectively. The largest individual narrow-sense heritabilities were found for LL (0.35), WL (0.34), SD (0.24), and HB (0.21), with accuracy corresponding to 64.2, 63.4, 56.8, and $64.3 \%$, respectively. Low coefficients of individual narrow-sense heritability were found for CD, SP and NB (Table 3).

\begin{tabular}{|c|c|c|c|c|c|c|c|c|}
\hline Genetic parameter & $\mathrm{PH}$ & NB & HB & $\mathrm{CD}$ & SD & LL & WL & SP \\
\hline$\hat{\sigma}_{a}^{2}$ & 57.085 & 0.049 & 2.257 & 7.796 & 31.545 & 0.780 & 0.816 & 0.774 \\
\hline$\hat{\sigma}_{p}^{2}$ & 57.285 & 0.052 & 0.096 & 30.458 & 34.628 & 0.162 & 0.191 & 1.166 \\
\hline$\hat{\sigma}_{e}^{2}$ & 201.190 & 0.489 & 8.370 & 116.263 & 62.200 & 1.233 & 1.347 & 5.810 \\
\hline$\hat{\sigma}_{f}^{2}$ & 315.560 & 0.590 & 10.724 & 154.517 & 128.373 & 2.175 & 2.353 & 7.750 \\
\hline$h_{a}^{2}$ & 0.181 & 0.083 & 0.210 & 0.050 & 0.246 & 0.358 & 0.347 & 0.010 \\
\hline$h_{a j}^{2}$ & 0.221 & 0.091 & 0.212 & 0.063 & 0.337 & 0.387 & 0.377 & 0.118 \\
\hline$h_{m p}^{2}$ & 0.326 & 0.210 & 0.464 & 0.113 & 0.360 & 0.558 & 0.545 & 0.219 \\
\hline $\begin{array}{l}m p \\
h_{a d}^{2}\end{array}$ & 0.175 & 0.070 & 0.168 & 0.048 & 0.276 & 0.322 & 0.312 & 0.091 \\
\hline $\mathrm{c}^{2}$ & 0.182 & 0.088 & 0.009 & 0.197 & 0.270 & 0.075 & 0.081 & 0.150 \\
\hline Accuracy & 53.77 & 42.71 & 64.32 & 29.59 & 56.84 & 64.23 & 63.40 & 38.57 \\
\hline CVgi (\%) & 16.32 & 16.03 & 17.95 & 7.40 & 14.90 & 7.84 & 7.83 & 7.76 \\
\hline CVgp (\%) & 8.16 & 8.02 & 8.97 & 3.70 & 7.45 & 3.92 & 3.92 & 3.88 \\
\hline CVe (\%) & 23.49 & 31.06 & 19.31 & 20.71 & 19.87 & 6.97 & 7.15 & 14.66 \\
\hline General mean & 46.30 & 1.38 & 8.37 & 37.71 & 37.69 & 11.26 & 11.53 & 11.34 \\
\hline
\end{tabular}

$\hat{\sigma}_{a}^{2}=$ additive genetic variance; $\hat{\sigma}_{p}^{2}=$ environmental variance among plots; $\hat{\sigma}_{e}^{2}=$ residual variance; $\hat{\sigma}_{f}^{2}=$ individual phenotypic variance; $h_{a}^{2}=$ individual narrow-sense heritability; $h_{a j}^{2}=$ individual narrow-sense heritability, adjusted for the effects of the plot; $h_{m p}^{2}=$ average progeny heritability; $h_{a d}^{2}=$ additive heritability in plot; $\mathrm{c}^{2}=$ coefficient of determination of the effects of the plot; CVgi = coefficient of individual genetic variability; $\mathrm{CVgp}=$ coefficient of genotypic variation among progenies; $\mathrm{CVe}=$ coefficient of residual variation. For other abbreviations, see legend to Table 2 .

\section{Genotypic correlation}

Genotypic correlations were determined between growth traits and seed traits of mother plants (Table 4). In particular, significant and positive genetic correlations were observed between LL and WL (0.91), PH and SD (0.81) and SW100 and LS (0.74). With regard to the OIL in seeds, the highest genetic correlations were observed with SD (0.20), PH (0.17) and SP (0.15). In fact, none of the growth traits showed significant genetic correlation with OIL in seeds (Table 4). With regard to the SW100, significant and positive correlations were found with LS (0.74), WS (0.61), PH (0.48) and WL (0.44).

\section{Genetic diversity}

The dendrogram generated using the UPGMA algorithm (considering a cutoff of $30 \%$ ), allowed the separation of progenies into eight clusters (Figure 1). Cluster II contained 
48 progenies, followed by cluster I (15 progenies), III (7 progenies), IV (4 progenies), and clusters V, VI, VII, and VIII with one progeny each.

\begin{tabular}{|c|c|c|c|c|c|c|c|c|c|c|}
\hline Variable & $\mathrm{NB}$ & $\mathrm{CD}$ & SD & LL & WL & $\mathrm{SP}$ & OIL & SW100 & LS & WS \\
\hline PH & 0.117 & $0.679 * *$ & $0.816^{* *}$ & $0.553 * *$ & $0.553^{* *}$ & $0.596^{* *}$ & 0.177 & $0.485^{* *}$ & $0.376^{* *}$ & $0.251^{*}$ \\
\hline NB & 1.000 & $0.457 * *$ & $0.364 * *$ & 0.063 & 0.036 & -0.039 & -0.001 & -0.153 & $-0.222^{*}$ & $-0.306^{* *}$ \\
\hline CD & & 1.000 & $0.720^{* *}$ & $0.522 * *$ & $0.455^{* *}$ & $0.489^{* *}$ & 0.022 & 0.210 & 0.099 & -0.018 \\
\hline SD & & & 1.000 & $0.443 * *$ & $0.405^{* *}$ & $0.341 * *$ & 0.207 & $0.345^{* *}$ & 0.197 & 0.120 \\
\hline LL & & & & 1.000 & $0.912 * *$ & $0.580^{* *}$ & 0.088 & $0.361 * *$ & $0.411^{* *}$ & 0.088 \\
\hline WL & & & & & 1.000 & $0.636^{* *}$ & 0.061 & $0.449 * *$ & $0.441^{* *}$ & 0.166 \\
\hline SP & & & & & & 1.000 & 0.155 & $0.401 * *$ & $0.305^{* *}$ & $0.303^{* *}$ \\
\hline OIL & & & & & & & 1.000 & 0.117 & -0.030 & -0.118 \\
\hline SW100 & & & & & & & & 1.000 & $0.740^{* *}$ & $0.615^{* *}$ \\
\hline LS & & & & & & & & & 1.000 & $0.656^{* *}$ \\
\hline
\end{tabular}

For abbreviations, see legend to Table $2 .{ }^{*}, * *$ Significant at 5 and $1 \%$, respectively.

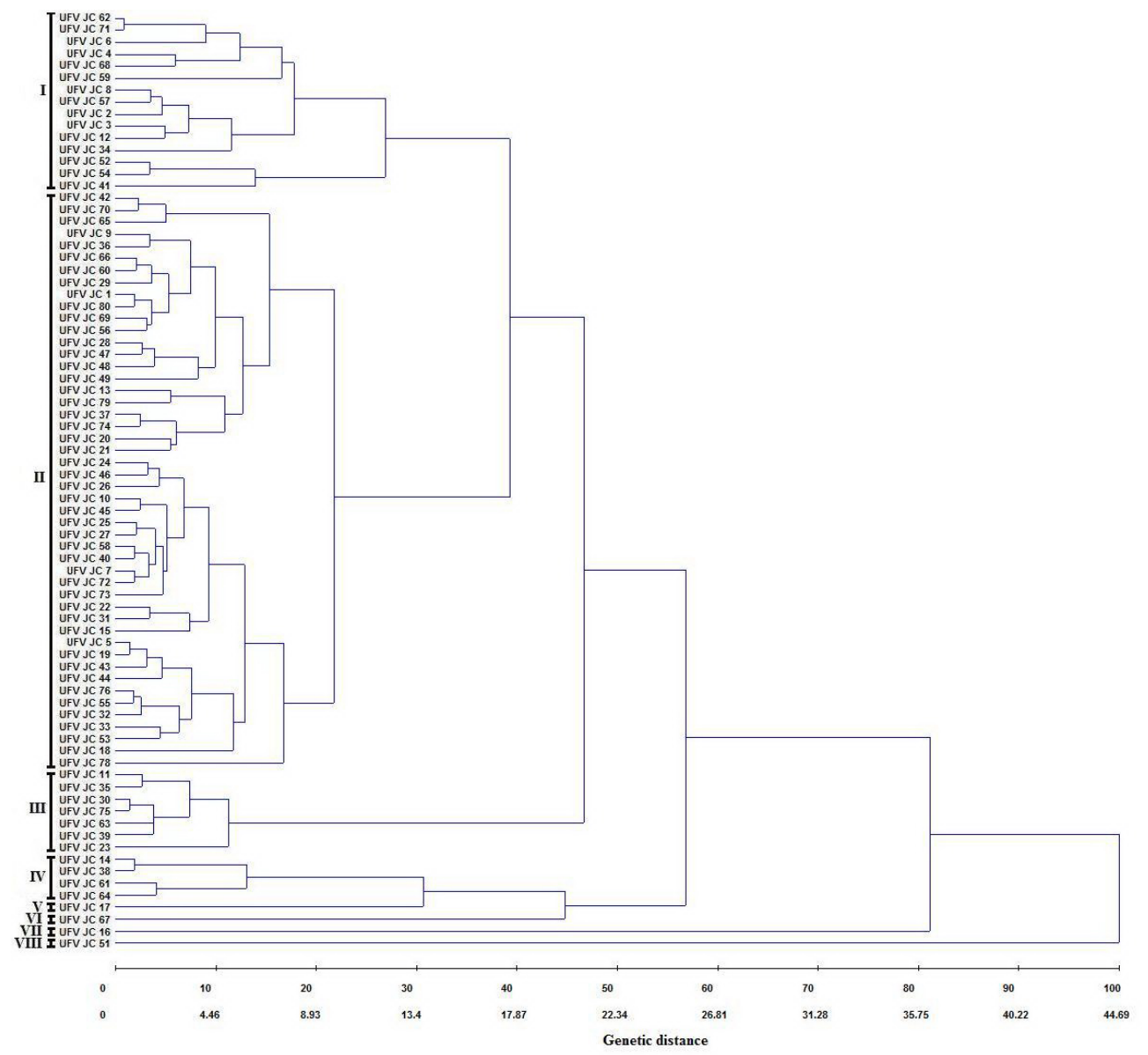

Figure 1. Dendrogram generated by UPGMA from the matrix of genetic quadratic Euclidean distance. 


\section{DISCUSSION}

This is the first study of genetic evaluation in $J$. curcas L. collected from different regions of Brazil. The results are important for breeding programs of the species. In Brazil, studies with $J$. curcas are just beginning, having been started intensively in the last two years. However, there are still no improved cultivars of Jatropha registered in the Ministry of Agriculture (MAPA) to meet the demand for planting on a commercial scale. Studies such as the present one, involving estimates of genetic parameters and variability in progenies in Brazil, can be useful in developing better cultivars of this important oilseed for biodiesel production.

The progenies of $J$. curcas were collected from different regions of Brazil and Cambodia. From the analysis of the seeds of mother plants, the average oil content was $31 \%$ (Table 2). There was high variability in the oil content of seeds, ranging from $16 \%$ from the progeny collected in the region of Jordânia up to $45 \%$ from the progeny of Poté, both cities in the State of Minas Gerais. For the other seed traits, as reported by Ginwal et al. (2005) and Kaushik et al. (2007), such as the 100-seed weight, length and width, high variations were also observed (Table 2). These results provide sufficient variability for the breeding program aimed at increasing productivity and oil content in Jatropha seeds.

Kaushik et al. (2007) evaluated 24 accessions of $J$. curcas from India and found an average oil content in seeds of 33\%, with a range of 28 to $38.8 \%$. Rao et al. (2008) evaluated 29 progenies of $J$. curcas L., also from India, and observed a range in oil content from 29.85 to $37.05 \%$, with a mean of $33.7 \%$. Higher values of oil content in seeds were obtained by Basha et al. (2009), who evaluated 72 accessions of $J$. curcas L. from 13 different countries, which showed a range of 45.4 to $64.5 \%$. However, the oil content described by Basha et al. (2009) was measured in relation to endosperm and not in relation to the mass of the entire seed. The oil content and seed yield of $J$. curcas vary considerably and can be attributed to several factors, such as genotype, rainfall and soil fertility (Mishra, 2009). The progenies evaluated in our study showed greater variability for oil content when compared with accessions in India, Mexico and Africa.

For $J$. curcas, there are still few studies of genetic parameter estimates, mainly due to the low degree of improvement of this species (Kaushik et al., 2007). Studies using molecular markers in accessions from India and China (Sun et al., 2008) indicate low genetic variability. In our study, a high degree of genetic variation was found for traits $\mathrm{HB}, \mathrm{PH}, \mathrm{NB}$, and $\mathrm{CD}$. Considerable heritability coefficients were also found for traits LL, WL, SD, and HB, indicating that potential selection gains can be obtained from these progenies. At two years, Rao et al. (2008) found a high heritability for plant height (0.87). The same authors found high broad-sense heritability for oil content (99\%), weight of 100 seeds (93\%) and seed width (77\%). In populations of India, Kaushik et al. (2007) found high heritability estimates for seed weight (0.96) and oil content (0.99).

Knowledge of the magnitude and direction of the genetic correlation is important in the choice of breeding methods and the formulation of strategies for simultaneous selection on multiple traits. Genotypic correlations indicate genetic association between characteristics. For seed traits in J. curcas, positive and highly significant correlations were observed between LL and WL, PH and SD and SW100 and LS (Table 4). Unlike what was reported by Ginwal et al. (2004) and Kaushik et al. (2007), no genetic association was detected with the oil content in seeds. The lack of correlation between LS and oil content was also found by Rao et al. (2008). 
The analysis of genetic distance and clustering are powerful tools to assess the relative contribution of different characteristics for total diversity, to quantify the degree of divergence between populations or accessions and to select divergent or genetically similar parents (Kaushik et al., 2007). In our study, the clustering pattern revealed that accessions from different geographical regions clustered together (Figure 1). These results are consistent with those obtained by Kaushik et al. (2007), and indicate that geographical diversity does not necessarily represent the genetic diversity among the accessions collected.

In breeding programs for hybrids, a cross of different genotypes is recommended. In this case, a good option is the crossing between progenies of cluster II with progenies from the other clusters (Figure 1). Dahmer et al. (2009) found chromosome stability in five J. curcas populations. This led the authors to conclude that the species is diploid $(2 \mathrm{n}=2 \mathrm{x}=22)$, and that the chromosomal stability is an advantage due to regular meiosis, to perform manual crosses between different accessions of the species. On the other hand, if the program's goal is to improve the recovery of some important parental characteristic, it is recommended to backcross between more similar accessions and among those accessions of the same cluster. With hybrids with high heterosis, the multiplication process by cloning can help in the development of $J$. curcas clones, since vegetative propagation methods are easily applied to this species (Divakara et al., 2009).

The three accessions from Cambodia evaluated in our study were grouped together with those of Brazil (Figure 1). This result may reflect the process of J. curcas L. dispersion. Evidence indicates that the center of origin of Jatropha is Central America, specifically Mexico. From Mexico, accessions were introduced to other Latin American countries (including Brazil) and later Africa and Asia.

The evidence from the results is promising regarding the existence of genetic diversity among the $J$. curcas accessions studied. These results are important for the continuity of breeding, especially in order to obtain cultivars with high yield and oil content in seeds. Further evaluations involving the same characteristics and others related to the reproductive cycle (male, female and hermaphrodite inflorescences) and production (number of fruits per bunch, number of seeds per fruit, and yield) can further expand the knowledge of $J$. curcas and promote the progress of the improvement of the species.

\section{ACKNOWLEDGMENTS}

Research supported by Conselho Nacional de Pesquisa e Desenvolvimento Tecnológico (CNPq) and Fundação de Amparo a Pesquisa do Estado de Minas Gerais (FAPEMIG).

\section{REFERENCES}

Basha SD and Sujatha M (2007). Inter and intra-population variability of Jatropha curcas (L.) characterized by RAPD and ISSR markers and development of population-specific SCAR markers. Euphytica 156: 375-386.

Basha SD, Francis G, Makkar HPS and Becker K (2009). A comparative study of biochemical traits and molecular markers for assessment of genetic relationships between Jatropha curcas L. germplasm from different countries. Plant Sci. 176: 812-823.

Bernardo R (2002). Breeding for Quantitative Traits in Plants. Stemma Press, Woodbury.

Cruz CD (2006). Genes Versão 2006.4.1: Programa Genes Versão Windows. Universidade Federal de Viçosa, Viçosa.

Dahmer N, Schifino-Wittmann MT and Dias LAS (2009). Chromosome numbers of Jatropha curcas L.: an important agrofuel plant. Crop Breed. Appl. Biotechnol. 9: 386-389. 
Dias LAS, Leme LP, Laviola BG and Pallini A (2007). Cultivo de Pinhão Manso (Jatropha curcas L.) para Produção de Óleo Combustível. Universidade Federal de Viçosa, Viçosa.

Divakara BN, Upadhyaya HD, Wani SP and Gowda CLL (2009). Biology and genetic improvement of Jatropha curcas L.: a review. Appl. Energy 87: 732-742.

Ginwal HS, Rawat OS and Srivastava RL (2004). Seed source variation in growth performance and oil yield of Jatropha curcas Linn. in Central India. Silvae Genet. 53: 186-192.

Ginwal HS, Phartyal SS, Rawat OS and Srivastava RL (2005). Seed source variation in morphology, germination and seedling growth of Jatropha curcas Linn. in Central India. Silvae Genet. 54: 76-80.

Heller J (1996). Physic Nut (Jatropha curcas L.). Promoting the Conservation and Use of Underutilized and Neglected Crops. International Board for Plant Genetic Resources, Roma, 161.

Jongschaap REE, Corré WJ, Bindraban OS and Brandenburg WA (2007). Claims and facts on Jatropha curcas L.: global Jatropha curcas evaluation, breeding and propagation programme. Plant Res. Int. Report 158.

Kaushik N, Kumar K, Kumar S, Kaushikb N, et al. (2007). Genetic variability and divergence studies in seed traits and oil content of Jatropha (Jatropha curcas L.) accessions. Biomass Bioenergy 31: 497-502.

Mishra DK (2009). Selection of candidate plus phenotypes of Jatropha curcas L. using method of paired comparisons. Biomass Bioenergy 33: 542-545.

Rao GR, Korwar GR, Shanker AK and Ramakrishna YS (2008). Genetic associations, variability and diversity in seed characters, growth, reproductive phenology and yield in Jatropha curcas (L.) accessions. Trees 22: 697-709.

Resende MDV (2007). Software Selegen-Reml/Blup. Embrapa Floresta, Colombo.

SAS Institute Inc. (1989). SAS/STAT User's Guide: Version 6. 4th edn. SAS Institute, Cary.

Sun QB, Li LF, Li Y, Wu GJ, et al. (2008). SSR and AFLP markers reveal low genetic diversity in the biofuel plant Jatropha curcas in China. Crop Sci. 48: 1865-1871. 